\title{
Short communication: Effect of storage temperature on the solubility of milk protein concentrate 80 (MPC80) treated with $\mathrm{NaCl}$ or $\mathrm{KCl}$
}

\author{
V. Sikand, ${ }^{*}$ P. S. Tong, ${ }^{* 1}$ J. Walker,† T. Wang,‡ and L. E. Rodriguez-Saonał \\ *Dairy Products Technology Center, and \\ †Statistics Department, California Polytechnic State University, San Luis Obispo 93407 \\ ‡Department of Food Science and Technology, The Ohio State University, Columbus 43210
}

\section{ABSTRACT}

A previous study in our laboratory showed that addition of $150 \mathrm{mM} \mathrm{NaCl}$ or $\mathrm{KCl}$ into diafiltration water improved the solubility of freshly made milk protein concentrate 80 (MPC80). In the present study, the objectives were (1) to evaluate the solubility of $\mathrm{NaCl}$ - or KCl-treated MPC80 samples kept at varying temperatures and then stored for extensive periods at room temperature $\left(21^{\circ} \mathrm{C} \pm 1^{\circ} \mathrm{C}\right)$; and (2) to determine if MPC80 samples stored at different temperatures and protein conformation can be grouped or categorized together. Freshly manufactured MPC80 samples were untreated (control), processed with $\mathrm{NaCl}$, or processed with $\mathrm{KCl}$. One set of sample bags was stored at $4^{\circ} \mathrm{C}$; second and third sets of bags were kept at $25^{\circ} \mathrm{C}$ and $55^{\circ} \mathrm{C}$ for $1 \mathrm{mo}$ $(31 \mathrm{~d})$ and then transferred to room temperature $\left(21^{\circ} \mathrm{C}\right.$ $\pm 1^{\circ} \mathrm{C}$ ) storage conditions for 1 yr $(365 \mathrm{~d})$. Samples were tested for nitrogen solubility index (NSI) and for protein changes by Fourier-transform infrared (FTIR) spectroscopy. Analysis of variance results for NSI showed 2 significantly different groupings of MPC80 samples. The more soluble group contained samples treated with $\mathrm{NaCl}$ or $\mathrm{KCl}$ and stored at either $4^{\circ} \mathrm{C}$ or $25^{\circ} \mathrm{C}$. These samples had mean NSI $>97.5 \%$. The less soluble groups contained all control samples, regardless of storage temperature, and $\mathrm{NaCl}$ - or $\mathrm{KCl}$-treated samples stored at $55^{\circ} \mathrm{C}$. These samples had mean NSI from 39.5 to $58 \%$. Within each of these groups (more soluble and less soluble), no significant differences in solubility were detected. Pattern recognition analysis by soft independent modeling of class analogy (SIMCA) was used to assess protein changes during storage by monitoring the amide I and amide II $\left(1,700^{-1}\right.$ to 1,300 $\mathrm{cm}^{-1}$ ) regions. Dominant bands were observed at 1,385 $\mathrm{cm}^{-1}$ for control, $1,551 \mathrm{~cm}^{-1}$ for KCl-treated samples, and $1,694 \mathrm{~cm}^{-1}$ for $\mathrm{NaCl}$-treated samples. Moreover,

Received July 22, 2015.

Accepted October 23, 2015.

${ }^{1}$ Corresponding author: ptong@calpoly.edu
SIMCA clustered the MPC80 samples stored at $4^{\circ} \mathrm{C}$ separately from samples stored at $25^{\circ} \mathrm{C}$ and $55^{\circ} \mathrm{C}$. This study demonstrates that (1) the addition of $\mathrm{NaCl}$ or $\mathrm{KCl}$ during MPC80 manufacture reduces the deleterious changes in solubility upon prolonged storage at $4^{\circ} \mathrm{C}$ or $25^{\circ} \mathrm{C}$, and $(2)$ the solubility of samples stored at $55^{\circ} \mathrm{C}$ is poor irrespective of salt treatment.

Key words: milk protein concentrate, salt treatment, solubility

\section{Short Communication}

Milk protein concentrates (MPC) are manufactured by ultrafiltration (UF) and diafiltration, followed by spray drying of skim milk. High-protein milk powders such as MPC with protein content ranging from 80 to $86 \%$ have been reported to exhibit low solubility (De Castro-Morel and Harper, 2002; Havea, 2006; Sikand et al., 2013). Havea (2006) reported that MPC85 (i.e., with $85 \%$ protein) powders stored at $20^{\circ} \mathrm{C}$ had $53 \%$ solubility after only $2 \mathrm{~d}$ of storage. On the other hand, high solubility (98\%) was reported even after 7 wk of storage of MPC85 when the calcium content of UF skim milk retentate was partially replaced by sodium ions via cation exchange process (Bhaskar et al., 2001). Thus, high solubility with low insoluble material in MPC80 and with low calcium was attributed to more electrostatic repulsive forces among the casein micelles. Similar effects of enhanced solubility were observed when 50 to $150 \mathrm{mM} \mathrm{NaCl}$ was added during the diafiltration step of MPC80 manufacturing (Mao et al., 2012). Those authors attributed the enhanced solubility to modification of hydrophobic sites and reduced disulfide contents.

Carr et al. (2002) reported significantly improved solubility for MPC85 samples treated with monovalent salt compared with that of untreated control samples. These samples were stored at $40^{\circ} \mathrm{C}$ for 0 to $4 \mathrm{wk}$. The improved solubility of salt-treated samples was observed upon powder reconstitution at temperatures ranging between $20^{\circ} \mathrm{C}$ and $40^{\circ} \mathrm{C}$ compared with the control samples. 
Several studies on poor solubility of MPC associated with increasing storage time, temperature, and humidity have been conducted (Anema et al., 2006; Le et al., 2011). However, there is no comprehensive study of solubility of MPC80 powders treated with monovalent salts $(\mathrm{NaCl}$ or $\mathrm{KCl})$ during the diafiltration $(\mathbf{D F})$ stage of MPC80 manufacturing and stored at different temperatures. Thus, a better understanding of age-related changes in MPC solubility is needed. The objectives of this study were (1) to evaluate the solubility of MPC80 powders treated with monovalent salts $(150 \mathrm{mM} \mathrm{NaCl}$ or $\mathrm{KCl}$ ), including one set of samples stored at $4^{\circ} \mathrm{C}$ for $1 \mathrm{yr}$; and 2 sets of samples at $25^{\circ} \mathrm{C}$ and $55^{\circ} \mathrm{C}$ for $1 \mathrm{mo}$ followed by storage at room temperature $\left(21^{\circ} \mathrm{C} \pm 1^{\circ} \mathrm{C}\right)$ for a period of $1 \mathrm{yr}(365 \mathrm{~d})$; and (2) to group or categorize the solubility of MPC80 samples treated with monovalent salts and stored at various temperatures with protein conformations as indicated by Fouriertransform infrared (FTIR) spectroscopy.

Milk protein concentrate powders were manufactured in the pilot plant of Dairy Products Technology Center at California Polytechnic State University (San Luis Obispo) with an R12 cross-flow membrane pilot-plant unit (Niro Inc., Hudson, WI) equipped with dual 10$\mathrm{kDa}$ cut-off spiral-wound polyethersulfone (PES) membranes (Synder Filtration, Vacaville, CA). In the MPC powder manufacture, pasteurized skim milk (140 kg) was concentrated up to $6 \times$. The UF milk was diafiltrated $(6 \times)$ before spray drying. During the DF stage, a premixed salt solution $(150 \mathrm{mM} \mathrm{NaCl}$ or $\mathrm{KCl})$ was used to wash the UF retentate. The DF process was repeated 3 times. The DF retentate was collected after the third washing of diafiltration and further spray dried by using a Niro Filterlab (Niro Inc.) unit. The manufacturing details for the MPC80 are described by Gualco (2010). The protein content of the MPC 80 powders was approximately $80 \%$.

Freshly manufactured MPC80 samples were untreated (control; MPC80-C) or treated with $150 \mathrm{mM}$ $\mathrm{NaCl}$ or $\mathrm{KCl}$ (MPC80-Na or MPC80-K). Two replicates of each sample were produced. Each sample was further split into 3 small bags. A total of 9 types of MPC80 samples were generated in 3 sets. All 3 sets of samples consisted of 3 types, MPC80-C, MPC80-Na, and MPC80-K. The MPC80 samples were packed in vacuum sealed bags $(18 \times 7 \times 4 \mathrm{~cm})$. The packaging material used was a multiwall foil gusset bag (Stock Bag Depot, China, CA) construction consisting of polyethylene terephthalate, aluminum, and linear low density polyethylene (PET/AL/LLDPE). The manufacturer's reported water vapor transmission rate on the bag was $0.00001 \mathrm{~g} / 100 \mathrm{in}^{2} /$ day measured at $37.8^{\circ} \mathrm{C}$. The packaging device used was a modified MVS 38 vacuum sealer (Minipack America Inc., Orange, CA). All of the
MPC80 powders were stored in vacuum-sealed bags and further enclosed in a multiwall foil gusset sample bag. One set of sample was stored at $4^{\circ} \mathrm{C}$ and not treated further. Second and third sets of samples were stored at $25^{\circ} \mathrm{C}$ and $55^{\circ} \mathrm{C}$, respectively, for $31 \mathrm{~d}$ and then both sets were transferred to room temperature $\left(21^{\circ} \mathrm{C} \pm 1^{\circ} \mathrm{C}\right)$ and stored for $1 \mathrm{yr}$.

For the present study, nitrogen solubility index (NSI) was used as measure of solubility, and FTIR spectroscopy analysis was used to determine any structural or conformational changes in the protein with respect to storage temperature of MPC80 samples.

The samples were prepared according to the method by Morr et al. (1985). The Vario Max analyzer (Hanau, Germany) was used to determine the nitrogen content in the samples. A conversion factor of 6.38 was used to convert nitrogen to protein content. One gram of sample was dissolved in $80 \mathrm{~mL}$ of deionized water and hydrated for $1 \mathrm{~h}$. The $\mathrm{pH}$ of each sample was adjusted to $\mathrm{pH} 7.0$ and the volume was made to $100 \mathrm{~mL}$ with deionized water. Samples were centrifuged at 20,000 $\times$ $g$ for $30 \mathrm{~min}$. The NSI was calculated as follows:

$$
\text { NSI }(\%)=\frac{\mathrm{N} \text { content in supernatant }}{\mathrm{N} \text { content in MPC80 dispersion }} \times 100 \% \text {. }
$$

Spectral data were collected using an Excalibur Series 3100 FT-IR spectrometer (Varian, Walnut Creek, CA) equipped with a dynamically aligned Michelson interferometer, a potassium bromide beam splitter, and a broadband mercury-cadmium-telluride (MCT) detector. Aliquots $(0.5 \mu \mathrm{L})$ of the MPC80 liquid samples (prepared per NSI test described in above section) were placed on a microscope slide and vacuum dried for 5 min to form thin films. The slide was placed directly onto the stage of a Varian 600 UMA FT-IR microscope (Varian, Randolph, MA), which was interfaced with the spectrometer and brought into contact with a slide-on attenuated total reflectance (ATR) germanium internal reflection element (Varian 600 UMA, Palo Alto, CA) for spectra collection. The spectra were collected using Resolution Pro Software (version 4.0, Varian) from 4,000 to $700 \mathrm{~cm}^{-1}$ with co-adding 128 scans to increase the signal to noise ratio. The absorbance spectrum was obtained by rationing the single beam spectrum against that of the air background. Soft independent modeling of class analogy (SIMCA), a multivariate technique based on principal component analysis, was used to discriminate among MPC80 samples treated and stored differently. Spectra were imported into Pirouette (version 4.0, Infometrix Inc., Bothell, WA), and chemometrics modeling software was used to perform the multivariate classification. Preprocessing methods such as normalization and second derivative were conducted 
Table 1. Effect of storage temperature $\left(4,25\right.$, or $\left.55^{\circ} \mathrm{C}\right)$ on control (MPC80-C) and monovalent salt-treated (MPC80-Na and MPC80-K) milk protein concentrate ( $80 \%$ protein) samples on nitrogen solubility index (NSI)

\begin{tabular}{lc}
\hline Sample type & $\begin{array}{c}\text { Nitrogen } \\
\text { solubility index }\end{array}$ \\
\hline MPC $80-\mathrm{C}\left(4^{\circ} \mathrm{C}\right)$ & $53.3^{\mathrm{b}}$ \\
MPC $80-\mathrm{Na}\left(4^{\circ} \mathrm{C}\right)$ & $100.0^{\mathrm{a}}$ \\
MPC80-K $\left(4^{\circ} \mathrm{C}\right)$ & $100.0^{\mathrm{a}}$ \\
MPC $80-\mathrm{C}\left(25^{\circ} \mathrm{C}\right)$ & $46.5^{\mathrm{b}}$ \\
MPC $80-\mathrm{Na}\left(25^{\circ} \mathrm{C}\right)$ & $97.5^{\mathrm{a}}$ \\
MPC $80-\mathrm{K}\left(25^{\circ} \mathrm{C}\right)$ & $97.5^{\mathrm{a}}$ \\
MPC $80-\mathrm{C}\left(55^{\circ} \mathrm{C}\right)$ & $39.5^{\mathrm{b}}$ \\
MPC $80-\mathrm{Na}\left(55^{\circ} \mathrm{C}\right)$ & $58.0^{\mathrm{b}}$ \\
MPC80-K $\left(55^{\circ} \mathrm{C}\right)$ & $51.0^{\mathrm{b}}$ \\
\hline
\end{tabular}

$\overline{\mathrm{a}, \mathrm{b}}$ Letters indicate groupings by Tukey's honestly significant difference (HSD) procedure using $\alpha=0.0167$. before classification to correct spectral data from drift in baseline and to resolve spectral bands (Zeaiter et al., 2005).

All analyses were done using a mixed model ANOVA in the statistics program JMP 9.0.2 (SAS Institute Inc., Cary, NC). The response variable in ANOVA was NSI. The factors were sample type (MPC80-C, MPC80-Na, MPC $80-\mathrm{K})$, temperature $\left(4^{\circ} \mathrm{C}, 25^{\circ} \mathrm{C}\right.$, and $\left.55^{\circ} \mathrm{C}\right)$, and replicate (1 and 2). A strong interaction effect was found between sample type and temperature $(P<$ 0.001 ). Differences between the 9 treatments (MPC80C, MPC $80-\mathrm{Na}$, and MPC $80-\mathrm{K}$ stored at $4^{\circ} \mathrm{C}, 25^{\circ} \mathrm{C}$, and $55^{\circ} \mathrm{C}$ ) were tested using Tukey's honestly significant differences (HSD) intervals using a Bonferroni-adjusted $1.67 \%$ individual significance level, which was used to

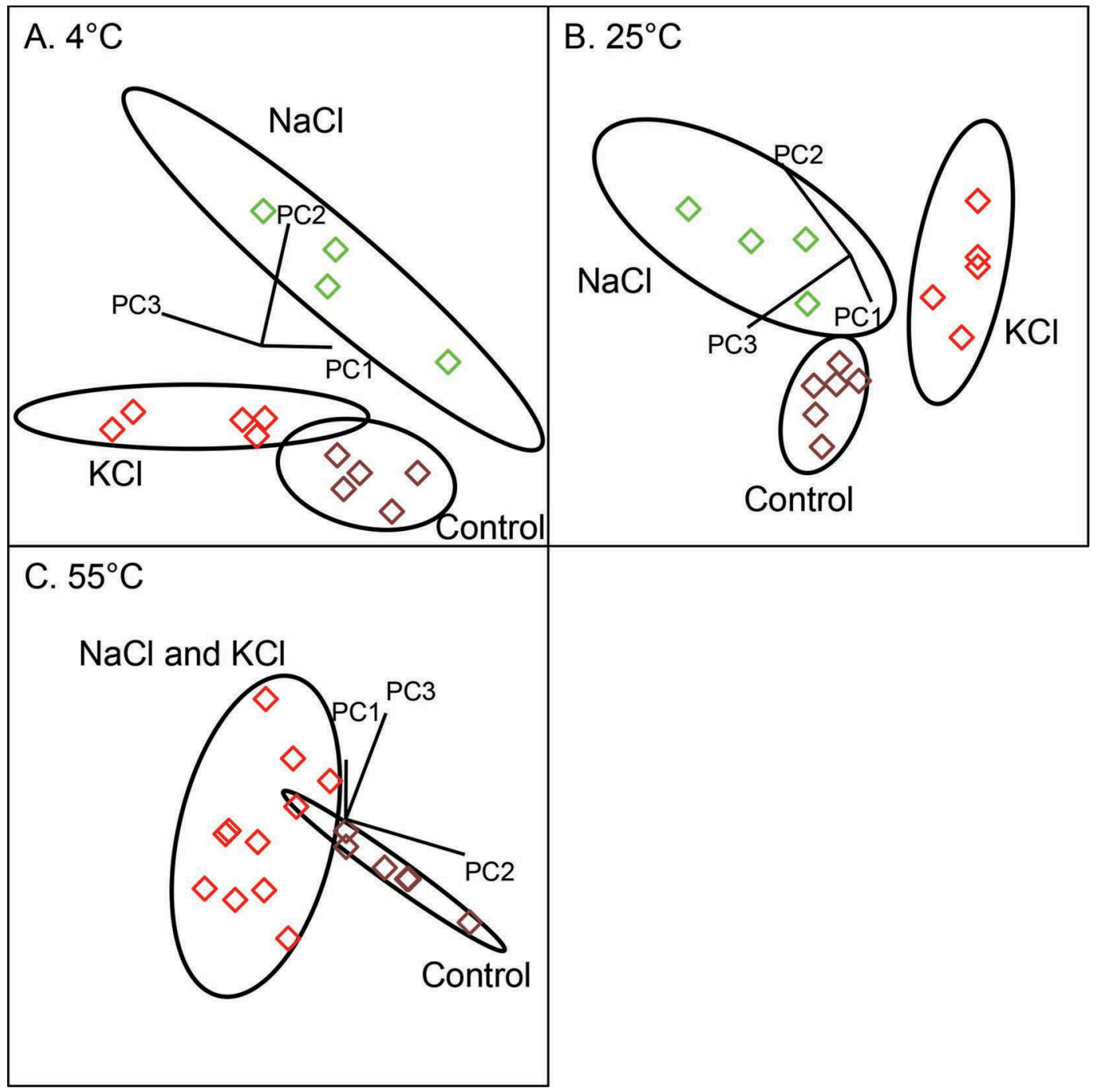

Figure 1. Soft independent modeling of class analogy (SIMCA) classification plots based on spectra collected from milk protein concentrate 80 (MPC80) liquid samples untreated (control) or treated with $\mathrm{NaCl}$ or $\mathrm{KCl}$ and stored at $4^{\circ} \mathrm{C}(\mathrm{A}), 25^{\circ} \mathrm{C}(\mathrm{B})$, and $55^{\circ} \mathrm{C}(\mathrm{C}) . \mathrm{PC}=$ principal component. Color version available online. 
test the 2 main effects and their interaction. The overall significance level for the analysis of NSI response variable was $5 \%$.

Table 1 shows that high NSI values (indicator of high solubility) were observed for MPC80-Na and MPC80$\mathrm{K}$ samples stored at $4^{\circ} \mathrm{C}$ and $25^{\circ} \mathrm{C}$ compared with the control sample. The MPC80-C samples, irrespective of storage temperature, had lower NSI (poor solubility) compared with MPC80-Na and MPC-K stored at $4^{\circ} \mathrm{C}$ and $25^{\circ} \mathrm{C}$. Jimenez-Flores and Kosikowski (1986) reported a decrease in solubility of retentate powders containing 50 to $60 \%$ protein after 4 wk of storage at $3{ }^{\circ} \mathrm{C}$. Our results are in agreement with previous reports of improved solubility of MPC80 treated with either monovalent salt (Sikand et al., 2013) or by replacing calcium with sodium (Bhaskar et al., 2001). A previous study by Sikand et al. (2013) demonstrated low calcium in MPC80 samples treated with $\mathrm{NaCl}$ or $\mathrm{KCl}$ compared with control samples. Those authors attributed the improved solubility of MPC80 powders to modified mineral and protein distribution in the colloidal and soluble phases of salt-treated samples. Similarly, Havea (2006) reported high solubility in MPC80 samples prepared by an ion-exchange method (Bhaskar et al., 2001), where calcium content was partially replaced by sodium ions. Those authors demonstrated no significant change in solubility of MPC80 samples when they were stored at $40^{\circ} \mathrm{C}$ for $50 \mathrm{~d}$. Improved solubility of MPC 80 with depleted calcium was attributed to increased repulsive interactions among casein micelles.

The current study demonstrated poor solubility of MPC80 samples irrespective of salt treatment stored at $55^{\circ} \mathrm{C}$ for 4 wk. Low solubility of MPC80 was found to increase with respect to increased time and temperature of storage (McKenna, 2000; Carr et al., 2002; Mistry, 2002; Anema et al., 2006; Kher et al., 2007; Haque et al., 2010). Anema et al. (2006) demonstrated by using mass spectroscopy that the casein became lactosylated at high storage temperature $\left(50^{\circ} \mathrm{C}\right)$. Lactosylation is one of the key steps in the Maillard reaction. Anema et al. (2006) reported that only a small amount of crosslinking is required to lessen solubility of MPC80.

The SIMCA classification plots (Figure 1) showed clustering among MPC80 samples treated with different salts and stored at different temperatures. Samples stored at $4^{\circ} \mathrm{C}$ (Figure 1A) showed clear separation among control, $\mathrm{NaCl}$, and $\mathrm{KCl}$ treatments. Samples stored at $25^{\circ} \mathrm{C}$ (Figure 1B) also clustered based on salts treatments; however, samples stored at $55^{\circ} \mathrm{C}$ (Figure 1C) formed 2 clusters, with samples treated with salts grouping together away from the control, which could support the results obtained from NSI, where no difference was found in the solubility of MPC80 stored at $55^{\circ} \mathrm{C}$, regardless of salt treatments.

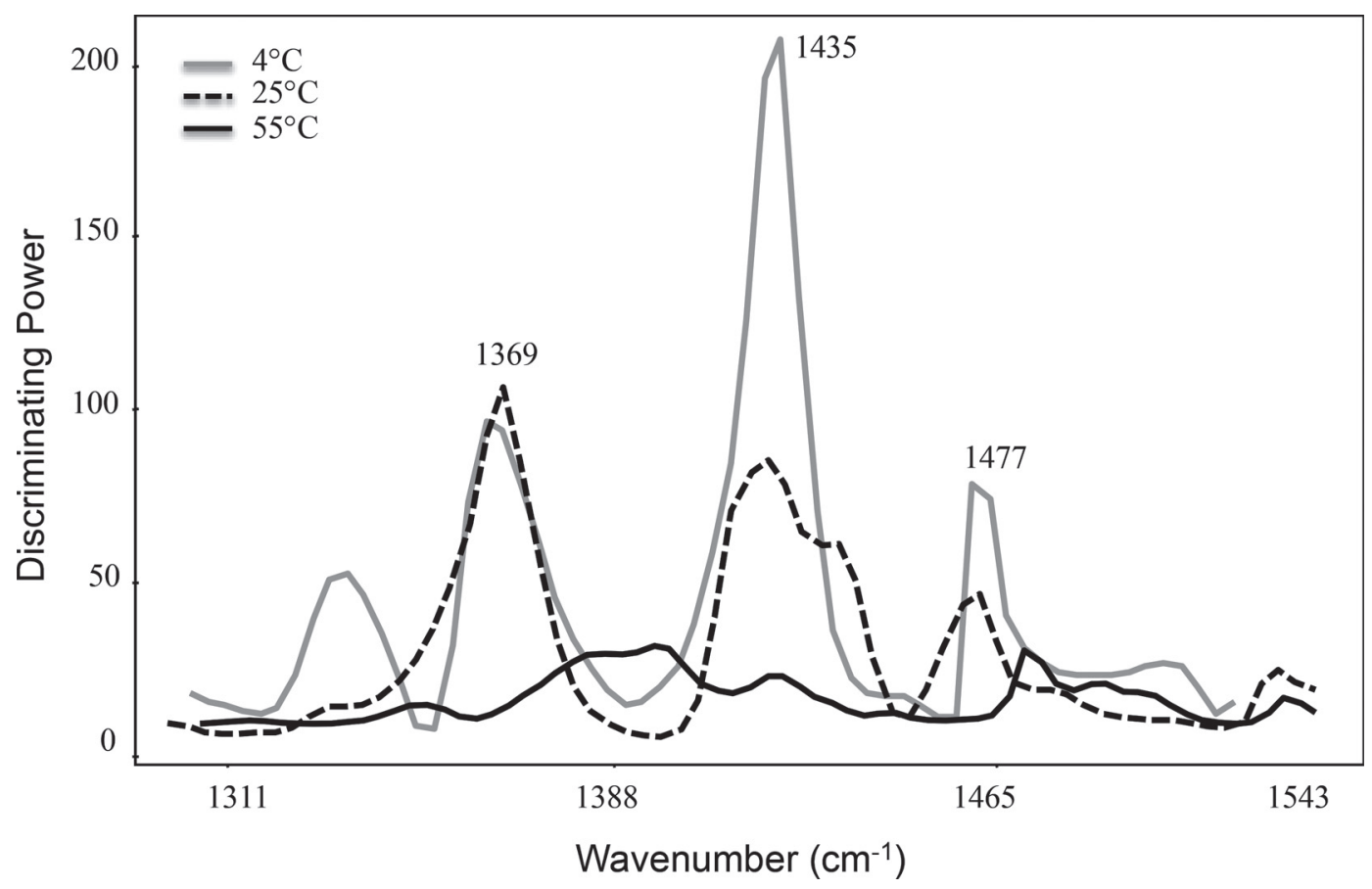

Figure 2. Soft independent modeling of class analogy (SIMCA) discriminating power based on the infrared spectra of milk protein concentrate $80(\mathrm{MPC} 80)$ liquid samples stored at $4^{\circ} \mathrm{C}(\mathrm{A}), 25^{\circ} \mathrm{C}(\mathrm{B})$, and $55^{\circ} \mathrm{C}(\mathrm{C})$. Band assignments: $1,369 \mathrm{~cm}^{-1}=$ carboxylate vibration of Asp; 1,435 $\mathrm{cm}^{-1}=\nu(\mathrm{CN})$ band; and the region $1,400-1,480 \mathrm{~cm}^{-1}=\mathrm{CH}_{2}$ and $\mathrm{CH}_{3}$ side chain deformations and benzene ring vibrations. 
Examination of the discriminating power for each classification plot provided information about functional groups responsible for the differentiation between classes. Similar bands were found to be important in the SIMCA classification of MPC 80 stored at $4^{\circ} \mathrm{C}$ (Figure $2 \mathrm{~A}$ ) and $25^{\circ} \mathrm{C}$ (Figure $2 \mathrm{~B}$ ), with bands centered at 1,369 and $1,377 \mathrm{~cm}^{-1}$, associated with the carboxylate vibration of Asp (Gerwert et al., 1989), being important in the classification. Another band that correlated with the discrimination of samples was that at 1,435 $\mathrm{cm}^{-1}$, which is related to backbone conformation of the $\nu(\mathrm{CN})$ band (Barth, 2000). These similar bands generated from SIMCA classification models for storage temperatures at $4^{\circ} \mathrm{C}$ and $25^{\circ} \mathrm{C}$ could explain why salt-treated samples had higher solubility than control samples. In contrast, MPC 80 stored at $55^{\circ} \mathrm{C}$ (Figure $2 \mathrm{C}$ ) showed limited discrimination between samples by pattern recognition analysis, probably because of the low solubility found for all proteins irrespective of salt treatments.

Overall, results obtained by FTIR combined with pattern recognition analysis showed discrimination between samples treated with different salts and stored at both $4^{\circ} \mathrm{C}$ and $25^{\circ} \mathrm{C}$, and showed the similarity of samples stored at $55^{\circ} \mathrm{C}$ regardless of salt treatment, supporting the data obtained from the NSI test. The results from our study indicate that salt treatments and storage temperatures resulted in changes of the carboxylate vibrations of Asp/Glu groups of acidic amino acids in milk proteins associated with cation chelation (Gerwert et al., 1989) and altered protein solubility.

Our results demonstrated that MPC80 powders treated with $\mathrm{NaCl}$ or $\mathrm{KCl}$ had high solubility even after $1 \mathrm{yr}$ of storage at 4 and $25^{\circ} \mathrm{C}$. We observed higher solubility in MPC80 samples treated with monovalent salts and further stored at $4^{\circ} \mathrm{C}$ and $25^{\circ} \mathrm{C}$. However, poor solubility was observed for control samples at all temperatures and for salt-treated samples stored at $55^{\circ} \mathrm{C}$.

\section{ACKNOWLEDGMENTS}

Financial support of this work by Dairy Research Institute (Rosemont, IL) and California Dairy Research Foundation (Davis, CA) is appreciated.

\section{REFERENCES}

Anema, S. G., D. N. Pinder, R. J. Hunter, and Y. Hemar. 2006. Effects of storage temperature on the solubility of milk protein concentrate (MPC85). Food Hydrocoll. 20:386-393.

Barth, A. 2000. The infrared absorption of amino acid side chains. Prog. Biophys. Mol. Biol. 74:141-173.

Bhaskar, G., H. Singh, and N. Blazey, inventors (published application). 2001. Milk protein concentrate products and process. International Patent Specification Pat. No. WO01/41578.

Carr, A., G. Bhaskar, and S. Ram, inventors (published application). 2002. Monovalent salt enhances solubility of milk protein concentrate. US Pat. No. 0208955.

De Castro-Morel, M., and W. Harper. 2002. Basic functionality of commercial milk protein concentrates. Milchwissenschaft 57:367-370.

Gerwert, K., B. Hess, J. Soppa, and D. Oesterhelt. 1989. Role of aspartate-96 in proton translocation by bacteriorhodopsin. Proc. Natl. Acad. Sci. USA 86:4943-4947.

Gualco, S. J. 2010. Effect of sodium chloride addition during diafiltration on the solubility of milk protein concentrate. MS Thesis. California Polytechnic State University, San Luis Obispo.

Haque, E., B. R. Bhandari, M. J. Gidley, H. C. Deeth, S. M. Møller, and A. K. Whittaker. 2010. Protein conformational modifications and kinetics of water-protein interactions in milk protein concentrate powder upon aging: Effect on solubility. J. Agric. Food Chem. 58:7748-7755.

Havea, P. 2006. Protein interactions in milk protein concentrate powders. Int. Dairy J. 16:415-422.

Jimenez-Flores, R., and F. Kosikowski. 1986. Properties of ultrafiltered skim milk retentate powders. J. Dairy Sci. 69:329-339.

Kher, A., P. Udabage, I. McKinnon, D. McNaughton, and M. A. Augustin. 2007. FTIR investigation of spray-dried milk protein concentrate powders. Vib. Spectrosc. 44:375-381.

Le, T. T., B. Bhandari, and H. C. Deeth. 2011. Chemical and physical changes in milk protein concentrate (MPC80) powder during storage. J. Agric. Food Chem. 59:5465-5473.

Mao, X., P. Tong, S. Gualco, and S. Vink. 2012. Effect of NaCl addition during diafiltration on the solubility, hydrophobicity, and disulfide bonds of $80 \%$ milk protein concentrate powder. J. Dairy Sci. 95:3481-3488.

McKenna, A. B. 2000. Effect of processing and storage on reconstitution properties of whole milk and ultrafiltered skim milk powders. PhD Thesis. Massey University, Palmerston North, New Zealand.

Mistry, V. 2002. Manufacture and application of high milk protein powder. Lait 82:515-522.

Morr, C. V., B. German, J. E. Kinsella, J. M. Regenstein, J. P. V. Buren, A. Kilara, B. A. Lewis, and M. E. Mangino. 1985. A collaborative study to develop a standardized food protein solubility procedure. J. Food Sci. 50:1715-1718.

Sikand, V., P. Tong, and J. Walker. 2013. Effect of adding salt during the diafiltration step of milk protein concentrate powder manufacture on mineral and soluble protein composition. J. Dairy Sci. Technol. 93:401-413.

Zeaiter, M., J. M. Roger, and V. Bellon-Maurel. 2005. Robustness of models developed by multivariate calibration. Part II: The influence of pre-processing methods. Trends Analyt. Chem. 24:437-445. 